\title{
Lost in Translation? Class Cleavage Roots and Left Electoral Mobilization in Western Europe
}

\author{
Vincenzo Emanuele
}

\begin{abstract}
I investigate whether the strength of the class cleavage in Western Europe still "translates" into the electoral mobilization of the left. This research question is addressed through comparative longitudinal analysis in nineteen Western European countries after World War II. In particular, the impact of class cleavage is investigated by disentangling its socio-structural (working-class features) and organizational (corporate and partisan) components, thus accounting for its multidimensional nature. Data show that both components have a significant impact in Western Europe after 1945. However, while the socio-structural element is still nowadays a substantial predictor of left electoral mobilization, the impact of the organizational element has decreased over time and has become irrelevant in the last twenty-five years. Therefore, the class cleavage is not entirely lost in translation, but left electoral mobilization is no longer dependent upon the organizational features of trade unions and political parties that originally emerged to represent working-class interests.
\end{abstract}

investigate whether and under what conditions the electoral mobilization of the Western European left is predicted by the strength of the class cleavage. The starting point of this investigation is represented by Bartolini's influential work (2000), a macro-historical analysis of thirteen Western European countries in the period 1860-1980. Bartolini found a robust and enduring association between different aspects of the class cleavage

A list of permanent links to Supplemental Materials provided by the authors precedes the References section.

Data replication sets are available in Harvard Dataverse at: https://doi.org/10.7910/DVN/YRLGNR.

\footnotetext{
Vincenzo Emanuele (D) is Assistant Professor in Political Science at Luiss, Rome (vemanuele@luiss. it). He is Co-Chair of the Research Network on Political Parties, Party Systems and Elections of the Council of Europe. His research, focusing mainly on elections and party system change, has appeared in Comparative Political Studies, West European Politics, Party Politics, South European Society and Politics, and Government and Opposition, among others. His monograph, Cleavages, Institutions, and Competition: Understanding Vote Nationalisation in Western Europe (19652015), has been published by Rowman \& Littlefield/ECPR Press.
}

(i.e., the presence of a strong industrial working class, high membership rates in trade unions and left-wing parties) and the electoral support for class bloc parties (i.e., communist, socialist, and social democratic parties). However, Bartolini's empirical results are drawn from the "golden age" of class politics, where the working class was strong and mainly industry-based, and class bloc parties and trade unions were powerful mass organizations. Moreover, Bartolini's analysis does not properly take into account the interactive dimension between class cleavage aspects and other factors that may moderate the association between class cleavage roots and left electoral mobilization. Amongst the many factors, the most important one is undoubtedly the evolution of this relationship across time. After several decades where the class cleavage was considered as the basis of politics and electoral competition and all else was instead "embellishment and detail" (Pulzer 1967), since the 1980s a large body of literature working on micro-level data has emphasized the decline of the class cleavage (Flanagan and Dalton 1984; Franklin, Mackie, and Valen 1992; Nieuwbeerta and Ultee 1999; Dalton 2002; Knutsen 2018). As a result, the validity of the link between left electoral mobilization and its historical class cleavage roots has to be put into question in recent decades, characterized by working-class shrinking and transformation, trade unions and left parties' organizational decline, and the alleged ideological shift of class bloc parties away from economic left goals 
(Mair 2008; Best 2011; Dalton 2013; Jansen, Evans, and De Graaf 2013; Rennwald and Evans 2014; Evans and Tilley 2012, 2017; Goldberg 2020). In other words, is the class cleavage still able to translate into the electoral support for the left? Or, instead, is left parties' support completely detached from its historical class cleavage roots? And which other intervening factors influence this relationship?

I address these research questions through a comparative longitudinal analysis in nineteen Western European countries in the period 1946-2018. In particular, the impact of class cleavage strength on the electoral mobilization of the class left is investigated through ecological data and by disentangling the class cleavage into different components related to its socio-structural and organizational elements, thus accounting for its multidimensional nature properly (Bartolini and Mair 2007).

Empirical analyses show that the different components of the class cleavage have a significant impact on the electoral support for the class bloc in Western Europe in the period 1946-2018. In particular, all else equal, a sizeable and industry-based working class and strong corporate and partisan organizations increase the electoral support for the class bloc. However, the temporal evolution of the association between class cleavage roots and left electoral mobilization shows that, while the sociostructural element is still nowadays a substantial predictor of the electoral support for the left, the impact of the organizational aspect has decreased over time and has become no longer significant in the last twenty-five years. Therefore, the class cleavage is not entirely lost in translation, as working-class characteristics are still relevant for predicting the electoral success of the left. However, the latter is no longer dependent upon the organizational features of trade unions and political parties that originally emerged to represent working-class interests. And even the programmatic emphasis left-wing parties put on economic left goals - which, in contrast to many scholarly claims, has not declined in recent years-is not sufficiently able to moderate the association between class cleavage roots and left electoral mobilization.

The article is organized as follows: in the next section I critically review the literature on class cleavage and its electoral consequences in Western European societies; the following section is devoted to raising hypotheses about the impact of the different class cleavage aspects on class bloc electoral support; then I introduce the dependent variable, discuss the methodological choices underlying the classification of parties within the class bloc, the national and temporal variations of their electoral support, and their programmatic emphasis; in the subsequent section I operationalize the independent and control variables and discuss the method used in the empirical analysis; lastly, I show the results of the empirical analysis; a conclusion follows.

\section{Class Cleavage and Left Electoral Mobilization: Theoretical Background}

The concept of cleavage lies in path-breaking studies by Lipset and Rokkan (1967) and Rokkan (1970). However, notwithstanding their extensive use of the concept for the formulation of their genetic theory of party systems, Lipset and Rokkan do not provide a clear definition of cleavage, whose meaning has remained loose and has been used for a long time as a synonym of division and conflict. As Bartolini $(2000,16)$ puts it, the concept of cleavage is "either reduced down to that of social cleavage or raised up to that of political cleavage." This is because the concept refers to both social structure and political order. Thus scholars often use the expression "social cleavage" or "political cleavage" depending on which aspect they want to emphasize.

In this regard, an important systematization comes from Bartolini and Mair (2007, 199). According to these authors, the concept of cleavage incorporates three elements: 1) the empirical referent of the concept, that is, the social group(s) arising from a conflict generated in the society, such as the working class (and, in reaction to it, the bourgeoisie) in the case of the class cleavage (empirical or socio-structural element); 2) a set of values and beliefs providing the social group(s) with a sense of identity and self-consciousness (cultural or normative element); and 3) an organizational structure (i.e., a political party) that coordinates and inspires the collective action of the social group and brings its interests into the political system (organizational element). This widely accepted definition resulting in the concept of cleavage involves at the same time socio-structural, ideological, cultural, organizational, and institutional elements. Therefore, it follows that a social conflict per se is not sufficient to have a cleavage. To be translated into a cleavage, a social conflict needs to generate a sense of identity and common beliefs and, most importantly, it needs to be politicized through the activity of an organization devoted to promoting its interests. At the same time, ideological or political issues without clearly defined social groups opposing each other cannot be defined as cleavages. ${ }^{1}$

Out of the four cleavages originally pointed out by Lipset and Rokkan, the class cleavage was the last to emerge but soon became the most important and most enduring one. It stemmed from the Industrial Revolution and gave rise at the corporate level to trade unions, and at the political and electoral levels, to socialist and social democratic parties that politicized the interest of the rising working class. While the other cleavages emerged only in certain contexts and not in othersaccording to specific cultural, socio-economic, or political conditions-the class cleavage spread across Europe and was politicized everywhere during the historical phases of democratization, enfranchisement, and 
development of mass politics (Lipset and Rokkan 1967; Rokkan 1970).

Given it was a so-called functional cleavage, with opposing social groups (working class vs. employers) based on ideas and interests and cutting across the territory of the respective country, the class cleavage historically played the role of a "homogenizing cleavage" in the process of nationalization of politics. Indeed, it created nonterritorial nationwide alignments with opposing socialist and social democratic parties representing the working class and with conservative and liberal parties advocating the threatened interests of the bourgeoisie (Caramani 2004).

As a fundamental pillar of the well-known "social cleavage model" (Lipset and Rokkan 1967), the alignment between the working class and its reference parties became "frozen" in the 1920s, modeled the shape of Western European party systems for decades and contributed to their long-term stability (Rose and Urwin 1970; Bartolini and Mair 2007; Oskarson 2005). Once structured in Western European countries, this cleavage became the foundation of the widespread left-right dimension of conflict that crystallized everywhere in Western Europe as the main dimension of political opposition in each party system (Fuchs and Klingemann 1990; Mair 2007).

Since the 1980s, the great bulk of studies about the class cleavage turned towards a micro-level perspective focusing on class voting, namely the association between voters' occupational class and vote choice. Although individual class voting is not the object of this study, it is important to underline some key findings of this literature that are deeply intertwined with the macro-level research about the socio-structural and organizational roots of left electoral mobilization. In this regard, since the 1980s the literature on class voting has observed a decline in the explanatory power of class differences on vote choice (Flanagan and Dalton 1984; Franklin, Mackie, and Valen 1992; Nieuwbeerta and Ultee 1999; Dalton 2002; Knutsen 2018). ${ }^{2}$ However, scholars disagree about the leading process causing such dealignment between class and vote choice.

On the one hand, a "behavioral dealignment" emerges as a result of a "proactive change of the electorate's preferences" (Goldberg 2020, 86). A generalized increase in societal affluence and better working conditions lead post-materialist values and "new politics" issues to enter the political debate. Consequently, individuals are more and more mobilized by individual leaders or according to specific issues (i.e., environment, multiculturalism, European integration) cutting across traditional class loyalties (Inglehart 1984; Kriesi 1998; Dalton 2002; Hooghe, Marks and Wilson 2002; Garzia 2014). As a result of changing habits and preferences, class divisions have become blurred and unable to explain differences in voting behavior (Clark and Lipset 2001).
On the other hand, the decline in class voting is also the result of globalization and de-industrialization processes. The industrial working class of Western democracies has shrunk in size, thus becoming electorally irrelevant (Best 2011). In other words, a "structural dealignment" has taken place, according to which "the importance of a cleavage has weakened simply because of a reduction or even 'extinction' of a social group, and not because the linking issue or subject has lost effect on vote choice" (Goldberg 2020, 70).

Beyond these two bottom-up perspectives, a top-down approach focusing on party strategies has also emerged. According to this strand of literature, the weakened link between social classes and reference political parties is not symptomatic of a dealignment of class. Rather, it is due to top-down processes in which political parties, particularly social democratic ones, have moderated their ideological orientation and reduced the emphasis on traditional economic left goals, thus favoring a substantial convergence with the mainstream right (Mair 2008; Dalton 2013; Evans and Tilley 2012, 2017). Thus, leftwing parties have appealed to different social groups, like public sector employees and socio-cultural professionals (Przeworski and Sprague 1986; Kitschelt 1994; Gingrich and Häusermann 2015; Benedetto, Hix, and Mastrorocco 2020). However, in so doing, they risk alienating the support of their traditional working-class base (Karreth, Polk, and Allen 2013; Abou-Chadi and Wagner 2019). ${ }^{3}$

While the top-down approach has the merit of putting party strategies back in the discussion, the role of parties (and trade unions) as organizational agencies of the class cleavage is a systematically neglected aspect of the literature on class voting, which instead focuses mostly on the socio-structural element of Bartolini and Mair's conceptualization (2007) introduced earlier. Indeed, the organizational element is properly recognized as an important aspect of the class cleavage in the macro-historical study by Bartolini (2000). He focuses on the socio-structural and the organizational elements of the class cleavage and finds a consistent and fairly stable link between class cleavage aspects and left electoral mobilization. Despite the presence of relevant national variations, he observes an overall robust and enduring association between the presence of a strong industrial working class, high membership rates in trade unions and left-wing parties, and electoral support for class bloc parties (communist, socialist, and social democratic parties). ${ }^{4}$ However, the current validity of Bartolini's empirical results should be put into question for two main reasons.

First, the results he gets are drawn from the "golden age" of class politics, where the working class was mainly industry-based, and class bloc parties and trade unions were strong mass organizations. By working on a different time frame (i.e., 1946-2018) characterized by working- 
class shrinking and transformation, trade unions and left parties organizational decline, and the previously discussed ideological shift of class bloc parties, will left electoral mobilization still be linked to the class cleavage's sociostructural and organizational roots?

Second, Bartolini's empirical analysis does not properly take into account the interactive dimension between class cleavage aspects and other important factors. For instance, as the socio-structural element is considered to be dependent upon the organizational one for the transformation of the social conflict into a proper cleavage (Bartolini 2000, 16-25), does the interaction between two class cleavage elements positively affect left electoral mobilization? Moreover, as class is not the only source of identity and conflict within a society, does the presence of rooted cultural (i.e., ethnic, linguistic, religious) cleavages crosscutting class loyalties undermine the association between class cleavage roots and left electoral mobilization? Finally, as emphasized by the top-down approach of class voting literature, party strategies are expected to influence the relationship between the socio-structural element (i.e., the working class) and the support for class bloc parties. Therefore, another question to be addressed is whether the emphasis class bloc parties put on traditional economic left goals affects the association between the strength of the working class and the support for these parties. In the following sections, I try to take a step forward in the study of class cleavage roots and their electoral consequences by empirically addressing all the mentioned research questions.

\section{Hypotheses}

In the effort of tracing class cleavage roots behind left electoral mobilization, we need to start from the sociostructural and organizational elements of the class cleavage introduced in the previous section. ${ }^{6}$

The socio-structural element of the class cleavage, its reference social group, is the working class. It is straightforward to hypothesize that a more favorable environment for the electoral success of the class left is a strong reference social group, namely a large and cohesive working class. While the latter can be generally considered as the group of people employed for wages, ${ }^{7}$ the sectors considered relevant to forming the socio-structural element of the class cleavage can be a matter of debate. The traditional conceptualization and interpretation of the "owner-worker" cleavage (Lipset and Rokkan, 1967) referred narrowly to the industrial working class. In particular, Bartolini (2000) argued that the strength of the working class could be mainly captured by two indicators, size and homogeneity. The former is the ratio between industrial workers and active population in a country and addresses the question of how large the putative social base of the class cleavage is. The latter, instead, refers to the ratio between the industrial working class and the entire working class and indicates to what extent the dependent labor force (i.e., the potential social base of the class cleavage) is industry-based rather than employed in agriculture or services. As for the size, the larger the industrial working class, the stronger the "social pressure of the group on its members toward attitudinal and behavioral conformity" (Bartolini 2000, 145). As a result, working-class size "fosters socialist political recruitment and mobilization" (ibid., 146). To a similar extent, homogeneity is at least as important as size. Indeed, regardless of its overall size, Bartolini (2000, 152-153) argues that the greater potential for class bloc electoral mobilization lies in the industrial sector rather than in agriculture-whose proletariat is organizationally unstable, volatile, and unable to exploit collective action. Moreover, service workers were traditionally considered either "an essentially conservative element within modern society" (Goldthorpe 1982, 180), or more likely to have postmaterialist or libertarian values compared to industrial workers (Inglehart 1977; Knutsen 2018).

More recently, however, the literature on class voting has tried to account for the increasing heterogeneity in the occupational structure, thus extending the working class beyond the industrial sector: scholars working on the "EGP class scheme" (Erikson, Goldthorpe, and Portocarero 1979) and those relying on the Oesch scheme (Oesch 2006) also consider farm laborers and service workers as among the working class. ${ }^{8}$ This more encompassing interpretation of the working class leads us to consider, besides a measure for those employed in the industrial sector, a measure covering the total working class, thus including the dependent labor force in agriculture and services. Our first hypothesis is as a result:

HypothesIs 1: The more sizeable and homogeneous the working class, the larger the electoral support for the class bloc.

The organizational element of the class cleavage involves both its corporate and partisan dimensions. The presence of strong organizations for the defense of the corporate and political interests of the working class is expected to be a crucial prerequisite for the electoral success of the class bloc. The underlying idea is that the more voters are encapsulated into the organization of trade unions, and even more, political parties representing their interests, the easier for such organizations to mobilize their putative constituency of voters (Bartolini 2000). ${ }^{9}$ Hence, the second hypothesis:

HyPOTHESIS 2: The denser the organizational encapsulation, the larger the electoral support for the class bloc.

Besides these two main hypotheses, we also expect some interactive effects involving the two main class cleavage aspects and their relationship with time or other contextual factors. 
To begin with, as the two aspects of the cleavage are deeply intertwined, we expect a positive interaction between them. On the one hand, the impact of a dense organizational encapsulation on the electoral support for the class bloc will be stronger the more powerful the reference social group is. This is because the organizational side of the cleavage is supposed to represent the armor of the otherwise politically defenseless working class: following this parallelism, the efficacy of the armor will also depend upon the strength of the body that wears it. On the other hand, as interaction effects are always symmetrical (Berry, Golder, and Milton 2012), we also expect that the marginal effect of the socio-structural characteristics of the class cleavage on left electoral mobilization will be stronger the denser the organizational network of the cleavage is itself. Indeed, the positive electoral mobilization effects triggered by a sizeable and homogeneous working class (i.e., a strong social group) are likely to be further stimulated and multiplied by the presence of rooted corporate and partisan organizations that translate working-class interests from the societal to the political arena. Therefore:

Hypothesis 3: The marginal effect of the organizational aspect of the class cleavage on the electoral support for the class bloc increases as the socio-structural aspect becomes stronger, and vice versa.

Regarding the impact of class cleavage aspects across time, scholars have long debated about the resilience (Rose and Urwin 1970; Bartolini and Mair 2007; Evans 2000; Elff 2007) vis-à-vis the decline of the class cleavage (Inglehart 1984; Franklin, Mackie, and Valen 1992; Clark and Lipset 2001; Dalton 2002; Knutsen 2018; Goldberg 2020). Yet most of this literature has addressed this topic through individual-level data to assess class voting decline. Conversely, I will test the effect of class cleavage roots on left electoral mobilization over time through aggregatelevel data that, "while less informative, offer a necessary longer-term perspective" (Bartolini and Mair 2007, 62). Consistently with the theory claiming class cleavage decline and dealignment in Western societies, we expect left electoral mobilization to be less linked to its class cleavage's socio-structural and organizational roots as time goes by. As a result:

Hypothesis 4: The marginal effect of the socio-structural and organizational aspects of the class cleavage on the electoral support for the class bloc decreases over time.

As far as other contextual factors are concerned, the presence of cultural cleavages is certainly expected to interact negatively with class cleavage aspects. Indeed, if the society is internally divided by ethnicity, language, or religion, this means that other allegiances also "crosscut" the working class, thus potentially undermining its ideological cohesion and sense of identity (see Rokkan 1970; Bartolini and Mair 2007; Lijphart 1999; Nieuwbeerta and Ultee 1999). Therefore, cultural (i.e., ethnic, linguistic, or religious) heterogeneity can be understood as a factor undermining the development of a strong identity among the members of the working class. As a result, the positive marginal effect of social group strength and organizational density on class bloc electoral support is expected to decrease as cultural heterogeneity increases. Putting it differently, when other sources of membership (i.e., ethnicity, language, religion) threaten or challenge the socio-structural and organizational aspects of the class cleavage, the latter will have a lower impact on the electoral return of the class bloc. Therefore, our fifth hypothesis:

HyPOTHESIS 5: The marginal effect of the socio-structural and organizational aspects of the class cleavage on the electoral support for the class bloc decreases as cultural heterogeneity increases.

Moreover, we also believe that supply-side strategies play a role in the story (Dalton 2013; Jansen, Evans, and De Graaf 2013; Rennwald and Evans 2014; Evans and Tilley 2012, 2017). Indeed, as class bloc parties are expected to represent the interests of their reference social group (i.e., the working class), the association between working-class size and homogeneity and support for class bloc parties will be closer the more class bloc parties are perceived as the legitimate delegates to represent workingclass interests. This outcome is expected to occur as far as class bloc parties emphasize traditional economic left goals (e.g., welfare expansion, market regulation, controlled economy, equality, support for labor groups), thus continuously and consistently feeding and reinforcing working-class loyalty. Conversely, as far as such parties de-emphasize traditional economic left goals in favor of other non-class-related policies, they become increasingly perceived as outsiders and their linkage to the working class progressively fades (Sartori 1982, 152-153). At the same time, the impact of the organizational element (especially CPD) on left electoral mobilization is also expected to be influenced by the extent to which such organizations emphasize their reference to class interests. In other words, if class bloc parties are not perceived as credible in their attempt to represent working-class interests, their organizations, albeit strong, become as "empty vessels" (Katz and Kolodny 1994) as far as left electoral mobilization is concerned. Therefore, we expect the following:

Hypothesis 6: The marginal effect of the sociostructural and organizational aspects of the class cleavage on the electoral support for the class bloc increases as class bloc emphasis on traditional left economic goals increases. 


\section{The Class Bloc: Composition, Electoral Support, and Programmatic Emphasis}

The empirical analysis starts from the identification and operationalization of the dependent variable, the electoral mobilization of the class left. As we are interested in a systemic-level study, where the observation is not an individual party politicizing the class cleavage but instead the overall electoral strength of all parties politicizing it in a given time and space, we will focus on an aggregate measure, namely the class bloc electoral support.

The first task is the definition of the "class bloc" and the identification of parties belonging to it. In this regard, by relying on Bartolini and Mair (2007) and Bartolini (2000), we consider the historical communist, socialist, social democratic, and labor parties that originally emerged to mobilize the working class and to represent its interests in national political life. In other words, we include "those parties which are the historical product of the structuring of the working class movement" (Bartolini and Mair 2007, 46), while parties of the "new politics" (Poguntke 1987; Müller-Rommel 1989), which emphasize issues like environmentalism, feminism, or civil rights, have always been excluded.

From a methodological viewpoint, we have excluded parties that have never received $1 \%$ of the vote share in parliamentary elections. This choice was made to exclude minor parties whose potential inclusion in the class bloc was hard to assess with a sufficient degree of precision given the scarce information available.

As a result, for thirteen Western European countries (Austria, Belgium, Denmark, Finland, France, Germany, Ireland, Italy, Netherlands, Norway, Sweden, Switzerland, and United Kingdom) included in the original studies by Bartolini and Mair $(2007,285)$ and Bartolini (2000, 573-574) that cover the period up to the 1980s, we followed these authors' criteria. However, as the class cleavage is not only a historical product but a dynamic concept, we have also carefully assessed the potential inclusion of all those parties that are direct successors of traditional working-class parties or new parties emphasizing traditional left issues. A qualitative assessment was needed to include class bloc parties in the aforementioned thirteen countries in recent years and in the remaining six countries (Cyprus, Greece, Iceland, Luxembourg, Portugal, and Spain) in the whole period. We have carefully considered all parties belonging to the communist, socialist, and social democratic party families in the ParlGov database (Döring and Manow 2019) and in the communist and socialist party families in the Comparative Manifesto Project Database (CMP) (Volkens et al. 2019). Then, by relying on the specific literature on these parties and party-related sources, we have excluded those parties that did not fit our substantive or methodological criteria. ${ }^{10}$ Table $\mathrm{A} 1$ in the online appendix reports the list of ninety-eight class bloc parties resulting from this classification.

Once the class bloc is defined and the parties belonging to it are identified, the second task is to assess variation in the class bloc electoral support. The latter can be operationalized as the aggregate vote share collected by class bloc parties in a given country in a given parliamentary election (Lower House).

Overall, the average electoral support for class bloc parties is $38 \%$ in the 349 elections under study. As clearly displayed by the quadratic line in figure 1 , the electoral support of class cleavage has proved to be substantially stable over time, with just a 3.5 percentage points variation over almost sixty-five years, namely from 1946 to 2010 (from the peak of $40.4 \%$ in the 1970 s to $36.9 \%$ in the 2000s). Finally, a noticeable reduction is shown in the last decade $(31.9 \%$ on average).

If we exclude Southern European countries where democracy comes back in the 1970s after the fall of the authoritarian regimes (Cyprus, Greece, Portugal, and Spain), and we focus only on the remaining fifteen countries where we have data points since the end of World War II, the electoral decline of the class bloc is more pronounced, with a range going from $40.2 \%$ in the $1960 \mathrm{~s}$ to $27.6 \%$ in the 2010 s. This means that to some extent the historical electoral decline of the class bloc in Nordic and Western European countries has been supplemented by the entry of electorally powerful class blocs in third-wave countries. At the same time, it highlights the importance of looking at national variations to gauge the phenomenon under study in greater detail. ${ }^{11}$

However, one may argue that the detected resilience of class bloc electoral support-albeit with a clear downward trend in the last decade- - has little or nothing to do with the hold of the class cleavage. Conversely, one may hypothesize that, while the class cleavage has deeply declined in Western European societies in terms of social composition and organization, parties that once appealed to the working class are still able to maintain a fairly stable electoral support as they have reoriented their programmatic platform by de-emphasizing economic left issues and promoting a catchall appeal (Kirchheimer 1966; Mair 2008; Dalton 2013; Evans and Tilley 2012, 2017). In other words, we could be in front of an issue of misplaced equivalence (Adcock and Collier 2001), as traditional left parties have maintained the same name and symbol but have changed their party platform compared to the 1960 s or 1970s and no longer emphasize traditional class left goals. Testing empirically whether class bloc parties have shifted ideologically away from traditional economic left goals over time is, therefore, a crucial preliminary step to verify the validity of our operationalization with reference to the class cleavage. Consistently with recent comparative and longitudinal analyses (Jansen, Evans, and De Graaf 2013; Adam and Ftergioti 2019) our empirical tests based 


\section{Figure 1}

\section{Electoral support for the class bloc over time in Western Europe (1946-2018)}

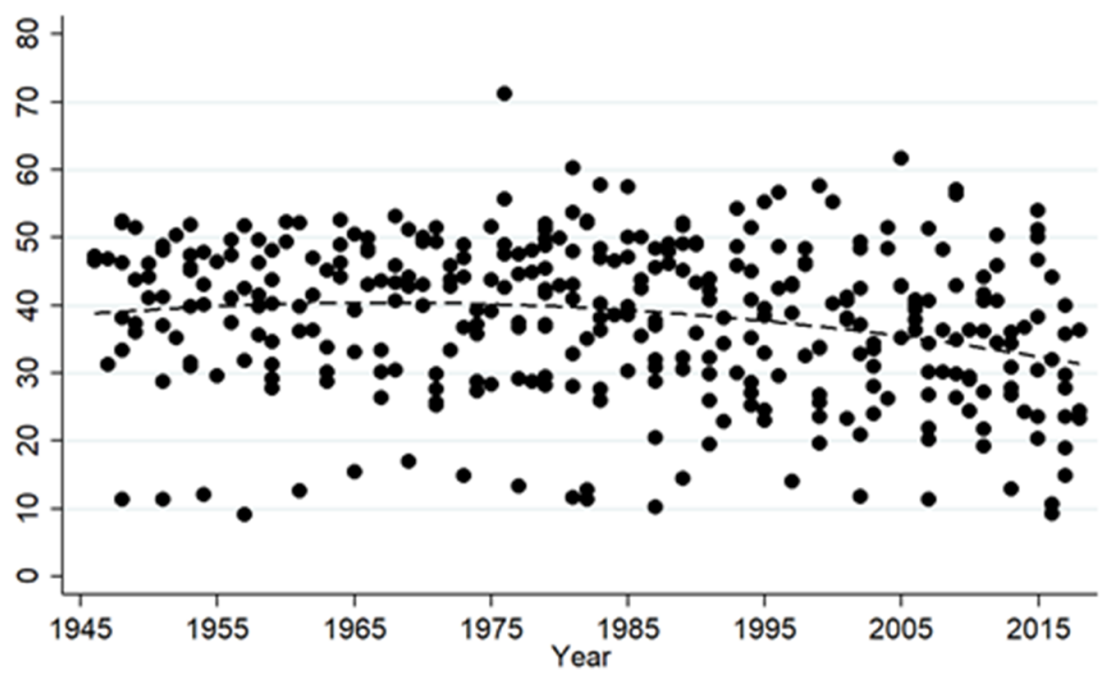

Note: The observations in the figure represent the aggregate vote share collected by class bloc parties in a given parliamentary election (Lower House). Class bloc parties are communist, socialist, social democratic, or labor parties that have received $1 \%$ of the vote share in parliamentary elections at least once in their electoral history. The complete list of class bloc parties is reported in table A1 in the online appendix.

on data from the CMP between 1945 and 2018 (Volkens et al. 2019) finds unequivocally that class bloc parties have not reduced their emphasis for traditional economic left goals over time (refer to table $\mathrm{A} 2$ and the related discussion in the online appendix). Therefore, the selected class bloc parties can be safely considered as the legitimate representatives of the working-class side of the class cleavage.

\section{Data and Method}

The operationalization of our main independent variables follows. Data about Industrial working-class size, Total working-class size, and Working-class homogeneity have been taken from Bartolini (2000) for earlier years (up to the 1970s), while for later ones the source is the International Labour Organization (ILO), supplemented by data from the Organization for Economic Cooperation and Development (OECD) in case of gaps in the ILO data. ${ }^{12}$ Following international standards and previous literature (e.g., Mainwaring and Zoco 2007), we define industrial workers as those dependent laborers employed in mining, manufacturing, construction, and transport. Preliminary regression models, reported in the online appendix (table A4), show that it is precisely the size of the industrial working class, rather than that of the working class as a whole (including agriculture and service workers) that matter for left electoral mobilization. Consequently, we have excluded total working-class size from the following analyses and, given that industrial working-class size and working-class homogeneity are highly collinear (Pearson's $r=.796)$, we have combined the two variables expressed in standardized forms into the index of Social group strength.

The level of organizational density can be captured through the use of two indicators (Bartolini and Mair 2007, 231-38; Bartolini 2000, 262-63). The first refers to the corporate channel and is Trade union density (TUD), which is the ratio between union membership and the total dependent labor force of a country. TUD data have been collected from Visser (2016). ${ }^{13}$ The second indicator instead refers to the partisan channel and is the ratio between class bloc parties' membership and the total electorate (Class partisan density, CPD). As regards CPD, the source for the collection of data on class parties' membership has been the MAPP Project Data Archive (Van Haute and Paulis 2016). ${ }^{14}$ As in the case of sociostructural factors, also TUD and CPD are tested separately and then combined into a standardized index of Organizational density.

By looking at figures 2 and 3 we get a synthetic scheme of the temporal evolution and national variations of the socio-structural and organization aspects of the class cleavage. To begin with, consistently with the vast literature emphasizing working-class shrinking and left parties' organizational decline (Dalton 2002, 2013; Mair 2008; Best 2011; Goldberg 2020), our data show that all classcleavage related variables decline over time. ${ }^{15}$ This general picture is fairly consistent across countries, as displayed by figure 2, which contrasts the temporal evolution of the two standardized indices of social group strength and 


\section{Figure 2}

Temporal evolution of social group strength and organizational density (1946-2018)
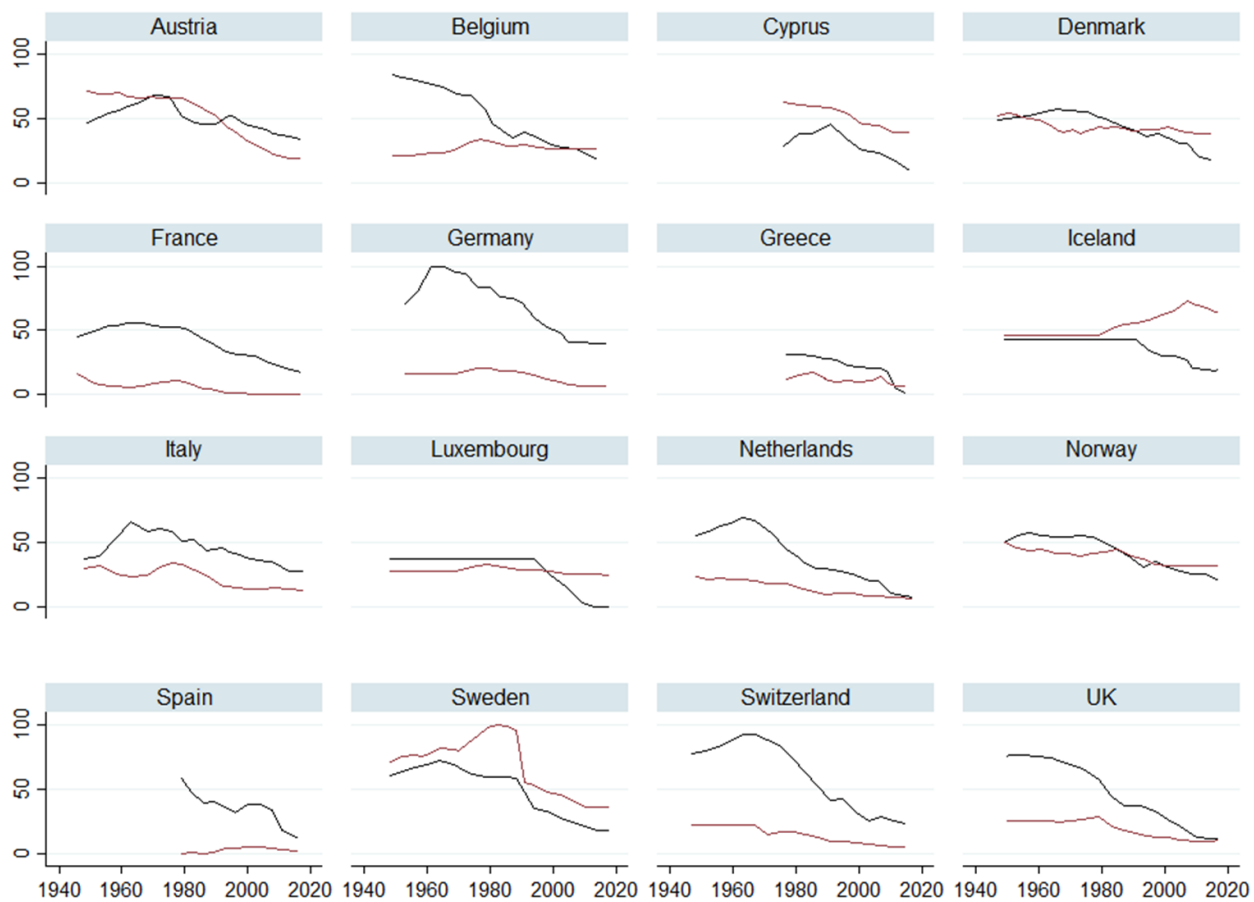

year

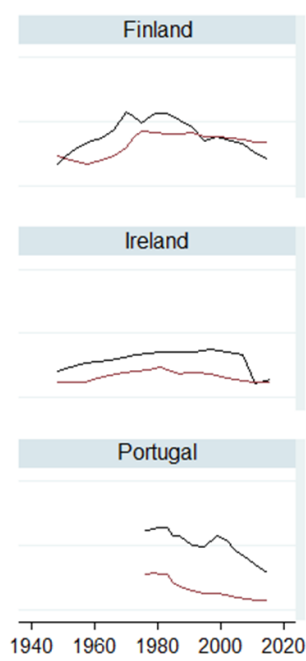

$\begin{array}{rrrrr}1940 & 1960 & 1980 & 2000 & 2020\end{array}$

\section{Social group strength}

\section{Organizational density}

Note: Social group strength and organizational density are synthetic indices combining variables expressed in standardized forms. The former combines industrial working-class size and working-class homogeneity. The latter combines class partisan density and trade union density. Both indices have been rescaled to a $0-100$ range.

organizational density (both rescaled to a 0-100 range to facilitate the comparison). Moreover, by contrasting country averages, as in the scatterplot of figure 3, interesting insights emerge. Indeed, the association between the two class cleavage-related aspects is lower than one might expect $(\mathrm{r}=.215)$. This means that the development of dense organizational networks (i.e., strong trade unions and left parties) is not necessarily linked to the presence of a sizeable and industry-based working class. This is the case of Germany and Switzerland-where a strong social group goes hand in hand with a comparatively weak organizational density—but also of Cyprus and Iceland, displaying the opposite situation of relatively strong organizations in a context of a small and heterogeneous working class. Not surprisingly, Scandinavian countries like Sweden and Denmark as well as Austria show the strongest class cleavage roots, while Greece and Ireland fall at the bottom of the rank. ${ }^{16}$

The impact of socio-structural and organizational roots of the class cleavage on class bloc electoral support is investigated also by looking at interaction effects with other factors (H4, H5, and H6). Specifically, Time is operationalized as the number of years elapsed since 1945. The addition of a trend variable is also particularly suitable in time-series analysis, as it provides control to problems of spurious correlations (Roberts and Wibbels 1999). The level of Cultural heterogeneity is assessed through the Fractionalization index (Alesina et al. 2003). The index ranges from 0 to 1 where 0 means perfect homogeneity (the whole population in a country has the same ethnicity, language, and religion), and 1 means perfect heterogeneity (there is a $100 \%$ probability that two randomly selected individuals within a population belong to different ethnic, linguistic, or religious groups). As Alesina et al. (2003) do not provide cross-temporal variation, we have collected data from Bartolini (2000) until the 1970s, and Patsiurko, Campbell, and Hall (2012) for the most recent period. ${ }^{17}$ To measure Class bloc emphasis on traditional economic left goals we have selected the following items in the CMP (Volkens et al. 2019): market regulation (per403), economic planning (per404), control of the economy (per412), Marxist 


\section{Figure 3}

\section{Social group strength and organizational density: country averages}

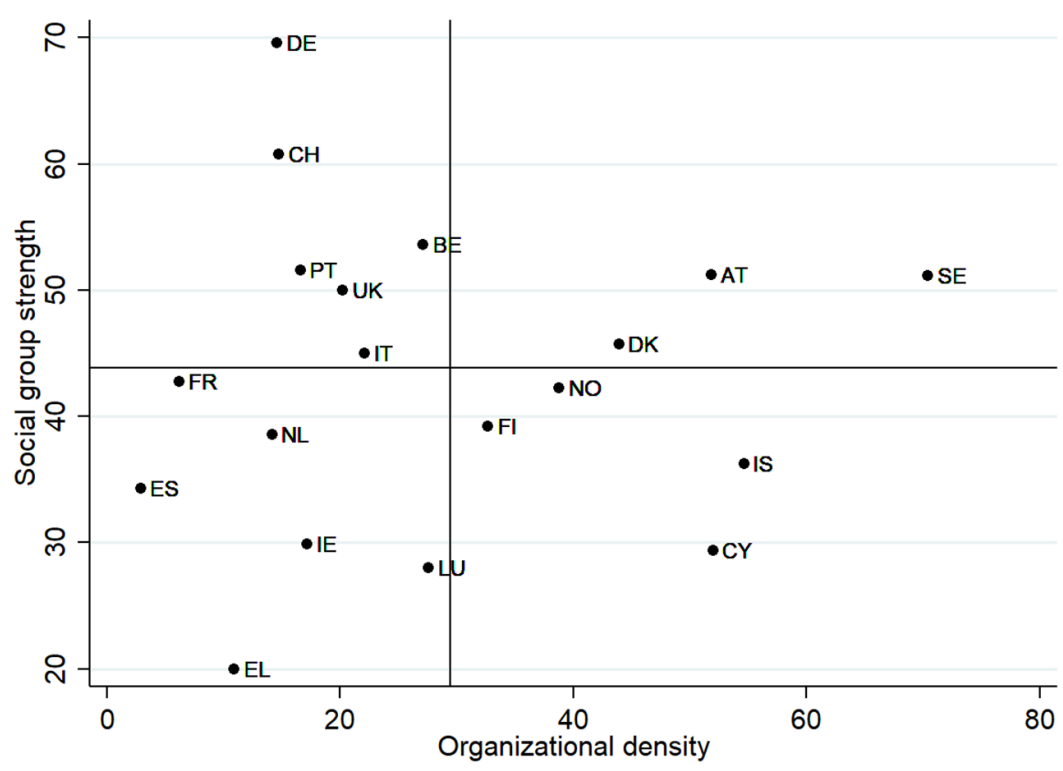

analysis (per415), equality (per503), welfare state (per504), and labor groups (per701). ${ }^{18}$ Then we have built an index that weighs, within each bloc, the individual party emphasis for the respective party's electoral support.

The empirical analyses will also be integrated by some other control variables that may have effects on the dependent variable. To begin, we control for the level of class bloc "Organizational cohesion" (Bartolini 2000), namely the number of parties included in the class bloc in a given country in a given election. ${ }^{19}$ We will then control for systemic properties such as the overall level of ideological polarization in the country (through Dalton's Polarization index $(2008)^{20}$ and the electoral system (through the natural log of the Average district magnitude, which is calculated by dividing the total number of seats to be allocated by the total number of districts). ${ }^{21}$ Furthermore, we will also add a dichotomous variable for Thirdwave democracies (Huntington 1991), namely Cyprus, Greece, Portugal, and Spain, where democracy came back only in the 1970s, and the class cleavage emerged in different structural conditions compared to the rest of Western Europe.

Figure 4 reports a synthetic scheme of all hypotheses, factors, measures, and expected effect on class bloc vote share, while table A3 in the online appendix reports the descriptive statistics of the dependent and (unlogged) independent variables.

From a methodological viewpoint, we deal with pooled time-series cross-section data (Beck and Katz 1995) with repeated observations over time (elections) on the same units (countries). In this context, problems of heteroscedasticity and autocorrelation may arise (Stimson 1985). Diagnostic tests such as an LR-test for panelheteroskedasticity $(\mathrm{p}<.001)$ and a Wooldridge test of autocorrelation $(\mathrm{p}<.05)$ (Drukker 2003) confirmed such concerns. Moreover, we have performed a Hausman test to compare the results of fixed and random effects models. The result is that $\mathrm{H} 0$ (i.e., the difference in the coefficients is not systematic) is not rejected and hence we can use a random effects model. Moreover, given that some covariates in the models are almost or completely time-invariant (e.g., average district magnitude, the dummy for thirdwave democracies), the inclusion of country-fixed effects is not recommendable (Beck and Katz 2007; Mainwaring, Gervasoni, and España-Najera 2017; Imai and Kim 2019).

Hence, in the next section, the previously raised hypotheses will be tested through a model specification that is able to tackle such issues deriving from the data structure. We opted for a Prais-Winsten regression, namely a panel-corrected standard errors method (PCSE) with a first-order autoregressive parameter (AR1). ${ }^{22}$

\section{Empirical Analysis}

Table 1 presents the results of the empirical models. Model 1 displays the general plain model, while Models 2-8 test the previously hypothesized interaction effects. $^{23}$ The general plain model tests $\mathrm{H} 1$ and $\mathrm{H} 2$, namely the hypothesized positive effect of, respectively, 


\section{Figure 4}

Synthetic scheme of hypotheses, factors, measures, and expected effect on class bloc vote share

\begin{tabular}{|c|c|c|c|}
\hline Hypothesis & Factor & Measures & $\begin{array}{l}\text { Expected Effect on } \\
\text { Class Bloc Vote Share }\end{array}$ \\
\hline H1 & Social group strength & $\begin{array}{l}\text { Industrial working-class size and Working- } \\
\text { class homogeneity }\end{array}$ & + \\
\hline $\mathrm{H} 2$ & Organizational density & $\begin{array}{l}\text { Trade union density (TUD) and Class } \\
\text { partisan density (CPD) }\end{array}$ & + \\
\hline H3 & $\begin{array}{l}\text { Class cleavage aspects' } \\
\text { mutual reinforcement }\end{array}$ & Social group strength ${ }^{*}$ Organizational density & + \\
\hline H4 & Class Cleavage and time & $\begin{array}{l}\text { Social group strength/Organizational } \\
\text { density*Time }\end{array}$ & - \\
\hline H5 & $\begin{array}{l}\text { Class cleavage and } \\
\text { cultural cleavages }\end{array}$ & $\begin{array}{l}\text { Social group strength/Organizational } \\
\text { density*Cultural fractionalization }\end{array}$ & - \\
\hline H6 & $\begin{array}{l}\text { Class cleavage and class } \\
\text { bloc parties' emphasis }\end{array}$ & $\begin{array}{l}\text { Social group strength/Organizational } \\
\text { density*Economic left emphasis }\end{array}$ & + \\
\hline \multirow[t]{7}{*}{ Controls } & Cultural heterogeneity & Fractionalization index & \\
\hline & Economic left emphasis & $\begin{array}{l}\text { Weighted index of Class bloc emphasis on } \\
\text { traditional economic left goals }\end{array}$ & \\
\hline & Organizational cohesion & Number of parties included in the Class bloc & \\
\hline & Ideological polarization & Polarization index & \\
\hline & Electoral system & $\begin{array}{l}\text { Average district magnitude (ADM) } \\
\text { Dummy variable for Cyprus, Greece, }\end{array}$ & \\
\hline & Third-wave democracies & Portugal, and Spain & \\
\hline & Time & Number of years since 1945 & \\
\hline
\end{tabular}

the socio-structural and the organization elements of the class cleavage on left electoral mobilization. ${ }^{24}$

The general plain model (Model 1) shows that both class cleavage factors emerge as positive and significant predictors of left electoral mobilization. As a result, $\mathrm{H} 1$ and $\mathrm{H} 2$ are confirmed. ${ }^{25}$ By comparing the effects of social group strength and organizational density, the latter shows a comparatively larger impact on left electoral mobilization. Indeed, as organizational density increases by one percentage point, class bloc vote share increases by 0.14 points against 0.11 in the case of a one percentage point increase of social group strength. ${ }^{26}$

Table A5 in the online appendix offers some robustness checks with a replication of Model 1 in Table 1 across three different model specifications: a feasible generalized least squares (FGLS) regression (Parks 1967) with a specification for panel heteroscedasticity and an autoregressive parameter (AR1); a panel-corrected standard errors regression (Beck and Katz 1995) without the specification for autocorrelation; a generalized linear model (GLM) estimator with logit link function (Costalli and Ruggeri 2019). Substantive results are consistent with those in table 1 across different specifications. ${ }^{27}$

So far, we have tested our first two hypotheses involving the linear effect of the two aspects of the class cleavage on the electoral success for the class bloc. We now turn to the analysis of the interactive models $(\mathrm{H} 3-\mathrm{H} 6)$, reported in table 1 (Models 2-8).

Starting from H3, Model 2 shows that the interaction between social group strength and organizational density is statistically significant (at $\mathrm{p}<.05$ ), as expected. This means that the marginal effect of organizational density on class bloc vote share increases as far as social group strength increases, and vice versa. As shown by the marginal plots reported in Figure 5, on the one side (right pane), the advantage of having a strong organizational network becomes tangible only at a certain level of industrial working-class size and homogeneity. In other words, with a meager and heterogeneous (i.e., not industry-based) working class, a powerful organization is not able to yield noticeable electoral returns. On the other side (left pane), the strength of the reference social group has an impact on the electoral support for the class bloc only if there is a certain level of organizational encapsulation.

Regarding H5, Models 5 and 6 of table 1 yield different results. While confirming the hypothesized negative interaction between class cleavage aspects and cultural heterogeneity, only social group strength is influenced by cultural cleavages in a statistically significant way (the interaction term is significant at $\mathrm{p}<.01$ ). More specifically, social group strength plays a significant role in the electoral success of the class bloc only when cultural heterogeneity is 
Table 1

Determinants of class bloc vote share in Western Europe after 1945

\begin{tabular}{|c|c|c|c|c|c|c|c|c|c|c|c|c|c|c|c|c|}
\hline & \multirow{2}{*}{\multicolumn{2}{|c|}{$\begin{array}{c}\text { Plain model } \\
\text { Model } 1 \\
\end{array}$}} & \multicolumn{14}{|c|}{ Interactions models } \\
\hline & & & \multicolumn{2}{|c|}{ Model 2} & \multicolumn{2}{|c|}{ Model 3} & \multicolumn{2}{|c|}{ Model 4} & \multicolumn{2}{|c|}{ Model 5} & \multicolumn{2}{|c|}{ Model 6} & \multicolumn{2}{|c|}{ Model 7} & \multicolumn{2}{|c|}{ Model 8} \\
\hline & b & pcse & b & pcse & b & pcse & b & pcse & b & pcse & b & pcse & b & pcse & b & pcse \\
\hline $\begin{array}{l}\text { Social group } \\
\text { strength }\end{array}$ & $0.111^{*}$ & 0.043 & 0.024 & 0.061 & $0.122 \dagger$ & 0.069 & $0.122^{\star *}$ & 0.043 & $0.266^{\star \star \star}$ & 0.077 & $0.111^{\star *}$ & 0.043 & 0.037 & 0.061 & $0.109^{*}$ & 0.043 \\
\hline $\begin{array}{l}\text { Organizational } \\
\text { density }\end{array}$ & $0.137^{\star \star *}$ & 0.038 & -0.052 & 0.095 & $0.137^{\star \star \star}$ & 0.038 & $0.298^{* *}$ & 0.067 & $0.121^{\star *}$ & 0.038 & $0.182^{\star *}$ & 0.064 & $0.139^{\star * *}$ & 0.038 & $0.120^{*}$ & 0.055 \\
\hline $\begin{array}{l}\text { Social group str. } \\
{ }^{*} \text { Org. density }\end{array}$ & - & - & $0.004^{\star}$ & 0.002 & - & - & - & - & - & - & - & - & - & - & - & - \\
\hline $\begin{array}{l}\text { Social group str. } \\
{ }^{*} \text { Time since } \\
1945\end{array}$ & - & - & - & - & -0.0003 & 0.002 & - & - & - & - & - & - & - & - & - & - \\
\hline $\begin{array}{l}\text { Org. density*Time } \\
\text { since } 1945\end{array}$ & - & - & - & - & - & - & $-0.004^{\star \star}$ & 0.002 & - & - & - & - & - & - & - & - \\
\hline $\begin{array}{l}\text { Social group str. } \\
{ }^{\star} \text { Fract. index }\end{array}$ & - & - & - & - & - & - & - & - & $-0.560^{\star \star}$ & 0.202 & - & - & - & - & - & - \\
\hline $\begin{array}{l}\text { Org. } \\
\text { density*Fract. } \\
\text { index }\end{array}$ & - & - & - & - & - & - & - & - & - & - & -0.249 & 0.253 & - & - & - & - \\
\hline $\begin{array}{l}\text { Social group str. } \\
{ }^{\star} \text { Economic left } \\
\text { emphasis index }\end{array}$ & - & - & - & - & - & - & - & - & - & - & - & - & $0.003+$ & 0.001 & - & - \\
\hline $\begin{array}{l}\text { Org. density* } \\
\text { Economic left } \\
\text { emphasis index }\end{array}$ & - & - & - & - & - & - & - & - & - & - & - & - & - & - & 0.001 & 0.002 \\
\hline $\begin{array}{l}\text { Fractionalization } \\
\text { index }\end{array}$ & $-9.762 \dagger$ & 5.622 & $-9.731 \dagger$ & 5.358 & $-9.929 \dagger$ & 5.627 & $-9.979 \dagger$ & 5.494 & 14.37 & 10.870 & -3.668 & 8.905 & $-9.446 \dagger$ & 5.657 & $-9.532 \dagger$ & 5.728 \\
\hline $\begin{array}{l}\text { Economic left } \\
\text { emphasis index }\end{array}$ & $-0.062 \dagger$ & 0.036 & $-0.068 \dagger$ & 0.037 & $-0.063 \dagger$ & 0.037 & $-0.061 \dagger$ & 0.036 & $-0.065 \dagger$ & 0.036 & $-0.065 \dagger$ & 0.037 & $-0.188^{\star}$ & 0.089 & -0.081 & 0.065 \\
\hline $\begin{array}{l}\text { N. parties in the } \\
\text { Class bloc }\end{array}$ & $1.032 \dagger$ & 0.579 & $1.018 \dagger$ & 0.564 & $1.037 \dagger$ & 0.579 & $0.954 \dagger$ & 0.570 & $0.974 \dagger$ & 0.571 & $1.06 \dagger$ & 0.576 & $1.023 \dagger$ & 0.576 & $1.031 \dagger$ & 0.581 \\
\hline Polarization index & 2.099 & 4.341 & 1.711 & 4.446 & 2.112 & 4.346 & 1.654 & 4.274 & 1.984 & 4.345 & 2.088 & 4.379 & 1.882 & 4.293 & 2.114 & 4.323 \\
\hline $\begin{array}{l}\text { Average district } \\
\text { magnitude (In) }\end{array}$ & 0.79 & 0.491 & 0.703 & 0.481 & 0.787 & 0.491 & $0.888 \dagger$ & 0.495 & 0.728 & 0.480 & 0.753 & 0.489 & 0.771 & 0.496 & 0.809 & 0.493 \\
\hline $\begin{array}{l}\text { Third-wave } \\
\text { democracies }\end{array}$ & $15.23^{\star \star \star}$ & 2.542 & $14.81^{* * *}$ & 2.312 & $15.22^{\star \star *}$ & 2.536 & $14.81^{\star \star \star}$ & 2.407 & $15.33^{\star \star \star}$ & 2.488 & $15.34^{\star \star \star}$ & 2.470 & $14.99^{\star \star \star}$ & 2.513 & $15.19^{\star \star \star}$ & 2.577 \\
\hline Time since 1945 & $-0.082 \dagger$ & 0.044 & $-0.073 \dagger$ & 0.043 & -0.071 & 0.078 & 0.046 & 0.067 & $-0.086^{\star}$ & 0.043 & $-0.081 \dagger$ & 0.044 & $-0.078 \dagger$ & 0.044 & $-0.084 \dagger$ & 0.044 \\
\hline $\begin{array}{l}\text { Constant } \\
R 2\end{array}$ & $\begin{array}{c}29.03^{\star \star \star} \\
0.479\end{array}$ & 4.261 & $\begin{array}{c}33.14^{\star \star \star} \\
0.487\end{array}$ & 4.776 & $\begin{array}{c}28.61^{\star \star \star} \\
0.479\end{array}$ & 4.945 & $\begin{array}{c}23.53^{\star * \star} \\
0.491\end{array}$ & 4.826 & $\begin{array}{c}23.35^{\star \star *} \\
0.489\end{array}$ & 4.947 & $\begin{array}{c}27.72^{\star \star \star} \\
0.481\end{array}$ & 4.611 & $\begin{array}{c}32.61^{\star \star \star} \\
0.483\end{array}$ & 4.762 & $\begin{array}{c}29.63^{\star \star \star} \\
0.479\end{array}$ & 4.493 \\
\hline Wald $\chi 2$ & $108.07^{* \star *}$ & & $141.83^{\star \star *}$ & & $110.98^{* * *}$ & & $130.62^{\star \star *}$ & & $118.87^{\star \star \star}$ & & $112.12^{* \star *}$ & & $112.63^{* * *}$ & & $106.11^{\star \star *}$ & \\
\hline $\mathrm{N}$ of elections & 345 & & 345 & & 345 & & 345 & & 345 & & 345 & & 345 & & 345 & \\
\hline $\mathrm{N}$ of countries & 19 & & 19 & & 19 & & 19 & & 19 & & 19 & & 19 & & 19 & \\
\hline
\end{tabular}




\section{Figure 5 Marginal effects on class bloc vote share of the interactions among the two aspects of the class cleavage}

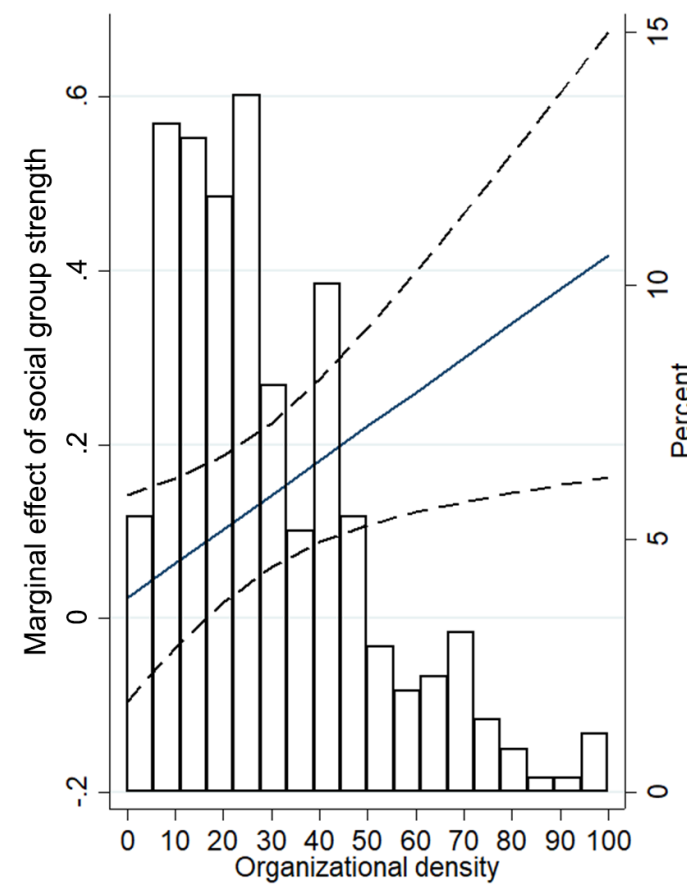

below a certain threshold, say 0.34 (80\% of the observations fall below this threshold; see also the marginal plot in figure 6). Conversely, dense corporate and partisan organizational networks play a positive and significant role on left electoral mobilization regardless of the extent to which the society is ethnically, linguistically, or religiously divided. $^{28}$

Turning to the interaction effect between the two class cleavage aspects and class bloc emphasis on traditional economic left goals (H6), Models 7 and 8 do not support our expectation. The organizational element of the class cleavage is shown to be unrelated to the extent that political parties appeal to their putative reference social group. In other words, organizations matter, regardless of the policy proposals they emphasize. ${ }^{29}$ The interaction between social group strength and class bloc emphasis on traditional economic left goals is positive and significant, but only at $\mathrm{p}<.10$. As a result, the more class bloc parties appeal to their putative social group, the closer the linkage between the working class and left electoral mobilization. However, following Berry, Golder, and Milton (2012, 660-662), that kind of effect is of trivial magnitude and, therefore, not substantively significant. The correct interpretation is therefore that the effect of social group strength on class bloc electoral support depends only slightly upon the extent to which class bloc parties emphasize traditional economic left goals. ${ }^{30}$

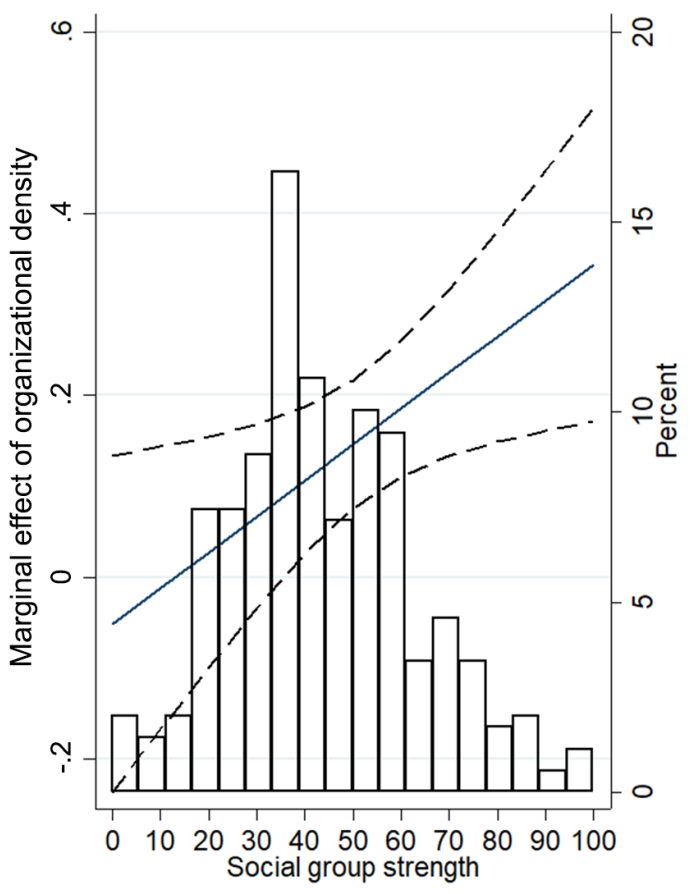

Finally, the results shown in Models 3 and 4 are surprising as they are partially against the expectation formulated in H4. Instead of showing unequivocally the declined class cleavage roots behind left electoral mobilization in Western Europe, Models 3 and 4 highlight a fundamental difference between the two aspects of the class cleavage. Indeed, as displayed by the steep negative slope of the marginal effect plotted in figure 7 , the association between organizational density and class bloc vote share has dramatically collapsed in recent years. On the contrary, in the case of social group strength (Model 3 ), the interaction with time is not significant, suggesting that the association between working-class features and class bloc vote share has not substantively declined in recent years.

As further robustness checks of $\mathrm{H} 4$, we have run separate regressions of the general model (Model 1 in table 1) for two time periods, with the cutoff point set in 1989 (see table A6 in the online appendix). The first period (19461989) shows that the two aspects of the class cleavage are significant predictors of class bloc electoral support (both at $\mathrm{p}<0.001)$. Conversely, in the second period (1990-2018), consistent with figure 7,31 the impact of organizational density becomes not significant, while that of social group strength maintains a significant impact on left electoral mobilization (albeit only at $\mathrm{p}<0.05$ ). As a result, $\mathrm{Hp} 4$ is only partially confirmed, and this finding sheds new light 


\section{Figure 6}

Marginal effect of social group strength on class bloc vote share at different levels of cultural heterogeneity

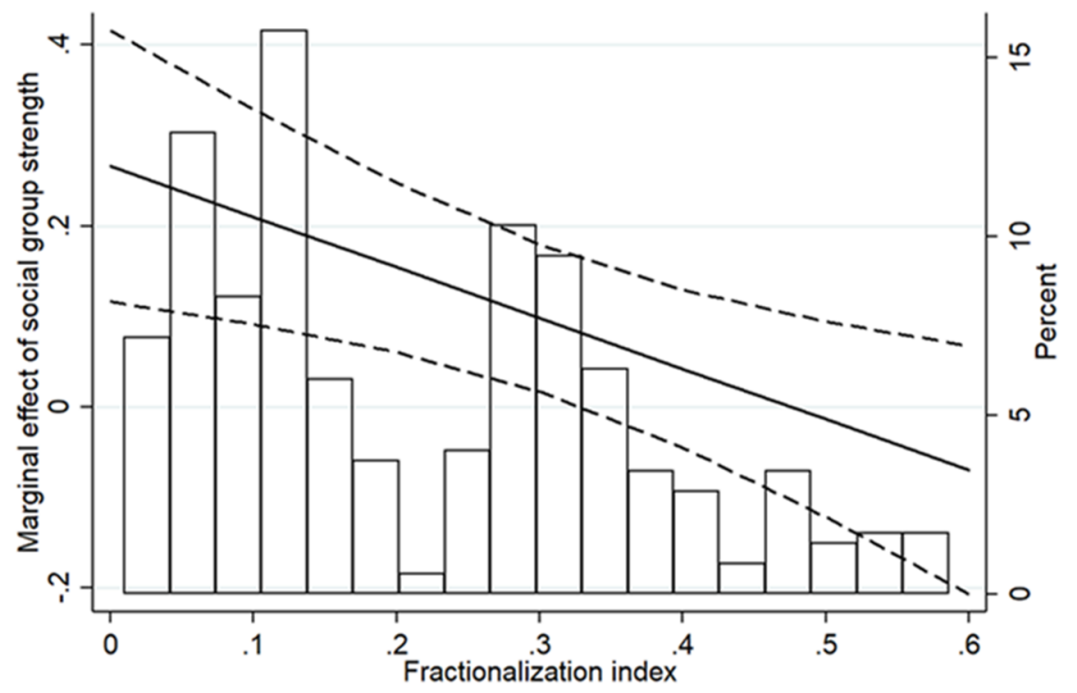

\section{Figure 7}

\section{Marginal effect of organizational density on class bloc vote share at different levels of time}

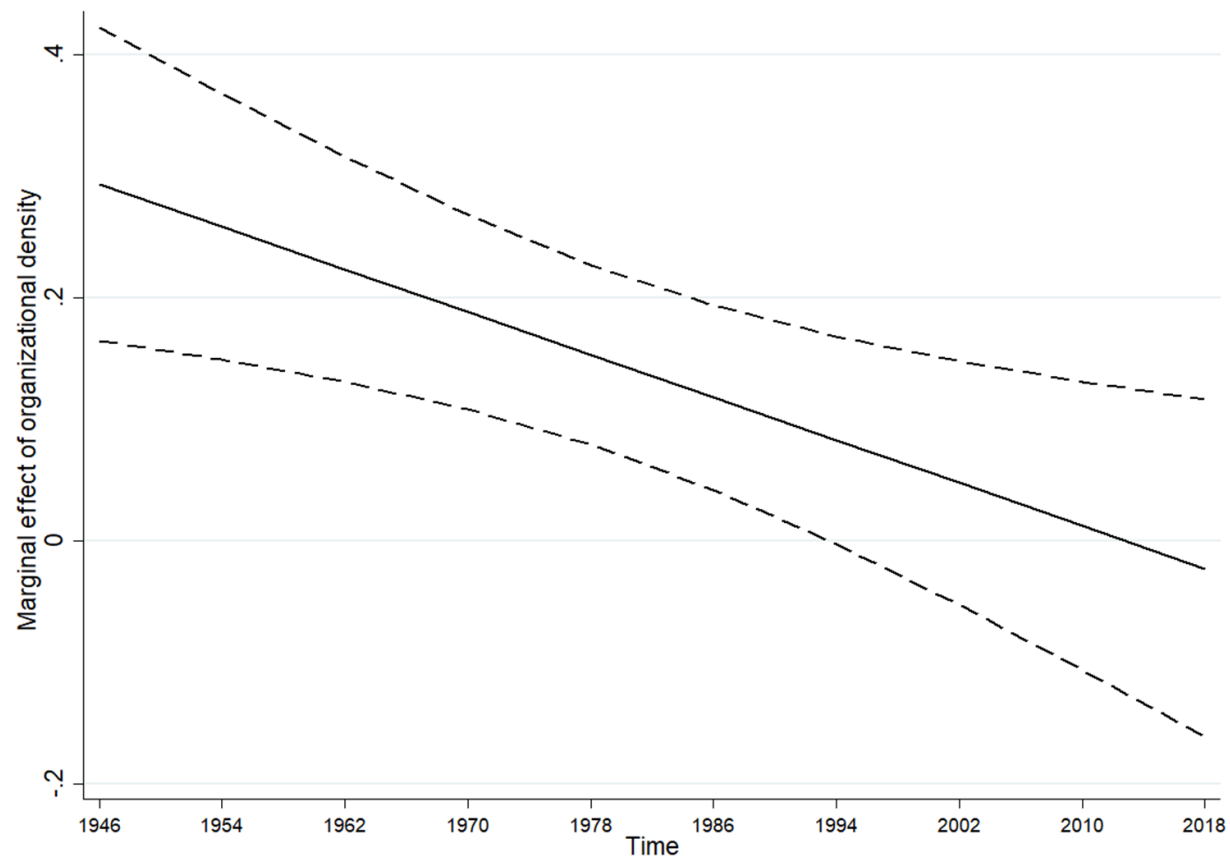

on the relationship between left electoral mobilization and its cleavage roots. In contrast to Bartolini's findings (2000), the organizational density, once the most important predictor of left electoral mobilization, no longer plays a significant role in the story. ${ }^{32}$
In other words, in the last twenty-five years, the electoral support for class bloc parties has been completely detached from the organizational density of the corporate and partisan channels that were alleged to represent working-class interests. However, the historical link 
between the industrial working class and the electoral support for class bloc parties has persisted over time and can be still detected nowadays. Therefore, notwithstanding the scholarly emphasis on class cleavage decline, there are still socio-structural class cleavage roots behind left electoral mobilization, although such mobilization no longer goes through the corporate and partisan organizations of the class cleavage.

\section{Conclusion}

I have investigated, through comparative longitudinal research design, the association between class cleavage's socio-structural and organizational roots and left electoral mobilization in nineteen Western European countries after 1945. I have advanced the research on class cleavage and its electoral consequences in different respects.

First, I have provided an original classification of class bloc parties in Western Europe after 1945. Such classification may travel beyond the scope of this study and become an important contribution for all scholars dealing with left-wing parties in Europe. Moreover, I have shown that class bloc electoral support has experienced a slight decline over time but is still electorally relevant as it has gathered about one-third of valid votes in the 2010s. In terms of national variations, the electoral decline is more pronounced in Nordic and Western countries, while Southern European ones have recently emerged as those with the largest electoral support for the class bloc.

Most importantly, through an original collection of a large amount of data coming from multiple sources, I have operationalized two aspects of the class cleavage, namely its socio-structural and organizational components. By doing so, it is possible to test empirically the impact of these aspects of class cleavage on its electoral translation, namely the electoral support for the class bloc. Moreover, this study has also tested how these aspects interact among each other as well as with other factors such as the presence of cultural cleavages and the programmatic emphasis class bloc parties put on traditional economic left goals. Finally, the study has also tested how the explanatory power of the two class cleavage-related aspects vary over time.

The empirical analyses yield relevant results for our understanding of the link between class cleavage roots and left electoral mobilization in Western Europe. Overall, both aspects of the class cleavage have a significant impact on the electoral support for the class bloc in Western Europe in the period 1946-2018. All else equal, a sizeable and industry-based working class (but not the agriculture- and service-based working class) and a dense organizational network increase the electoral support for the class bloc. Therefore, our study confirms that Bartolini's findings (2000) still hold in the aggregate also by expanding both the spatial and the temporal scope of its original analysis. But this study goes beyond Bartolini's findings by delving deeper into the relationship between class cleavage aspects and other intervening factors. Here, other important original findings emerge.

First, the two aspects of the class cleavage tend to reinforce each other through positive interaction effects. Second, the impact of the socio-structural roots of the class cleavage is also negatively influenced by the level of cultural heterogeneity in the society. Cultural divides crosscut the working class and undermine class loyalties. Therefore, as far as ethnic, linguistic, and religious heterogeneity increases, the effect of the sociostructural element on left electoral mobilization decreases.

Third, in contrast to many scholarly claims, class bloc parties have not reduced their emphasis on traditional economic left goals. However, this supply-side factor seems to be substantially irrelevant in the association between the two class cleavage-related aspects and left electoral mobilization.

Finally, the temporal evolution of the relationship between class cleavage roots and left electoral mobilization is only partially in line with the scholarly claim about class cleavage decline. Indeed, while the impact of the organizational aspect has decreased over time and has become no longer significant in the last twenty-five years, the sociostructural element has not, and it is still a substantial predictor of left electoral mobilization.

In a nutshell, the class cleavage is not entirely lost in translation, as a sizeable and industry-based working class is still an important predictor today of left electoral mobilization. But such mobilization is no longer mediated by the corporate and partisan organizations, the original vectors of cleavage translation. Indeed, membership in trade unions and left-wing parties are no longer associated with left electoral support, but even the extent to which left-wing parties emphasize economic left goals is not sufficiently able to moderate the association between class cleavage roots and left electoral mobilization.

These results deserve careful future consideration and have important implications for the study of cleavages and elections. In particular, they raise fundamental questions about the future of class bloc parties and their class cleavage roots. Will the persistent link between class cleavage's socio-structural roots and left electoral mobilization be a sufficient factor for class bloc parties' electoral resilience, despite the missing link with class cleavage's organizational roots? Or, instead, will the breakage of the transmission belt between organizational density and left electoral mobilization cause an electoral disintegration of these parties in the near future? Further research should carefully address these questions, whose answer is of paramount importance for our understanding of class politics and electoral competition in twenty-first century Europe. 


\section{Acknowledgement}

A previous version of this article was presented at the XXXIII SISP Congress, Lecce, September 11-14, 2019, and at the XII International SISE Conference, Rome, December 5-6, 2019. I warmly thank Lorenzo De Sio, Alessandro Chiaramonte, Paolo Bellucci, Paolo Barisione, Giorgio Malet, Julia Schulte-Cloos, Elisa Volpi, Davide Angelucci, Alberto Stefanelli, Federico Trastulli, and Bruno Marino for their comments and suggestions on earlier versions of the article.

\section{Supplementary Materials}

To view supplementary material for this article, please visit http://dx.doi.org/10.1017/S1537592721000943.

\section{Notes}

1 On this point, see the discussion in Bartolini 2000, 16-25.

2 On the different generations of class voting research, see Knutsen 2007.

3 Notice that the three approaches, rather than being independent from each other, are clearly interrelated; a structural dealignment and the dramatic decline in the size of the traditional class gardée lead left-wing parties to appeal to different social groups in order to successfully compete in the electoral arena. As a result of this programmatic and ideological change, a behavioral dealignment is also an expected outcome, as social group divisions are less likely to produce clearcut vote choices.

4 Other scholars aiming at measuring class cleavage strength through ecological data chose to focus on either the organizational aspect only (i.e., trade union and left parties' membership density; see Bartolini and Mair 2007; Roberts and Wibbels 1999; Emanuele 2018) or on both socio-structural (i.e., industrial working-class size) and organizational elements; Mainwaring and Zoco 2007.

5 In this regard, Benedetto, Hix, and Mastrorocco 2020 find mixed evidence about the relationship between the share of workers employed in industry and social democratic vote share. Indeed, the share of industrial workers is a significant predictor of the support for social democratic parties since 1975, but such association is no longer significant since 2000 .

6 Consistent with previous literature, the normative element (i.e., class identity and consciousness) is excluded from the analysis as it is not systematically available for the temporal and spatial scope of this study. On the difficulty to measure this aspect of the class cleavage, see also Bartolini and Mair 2007, 208, and Bartolini 2000, 28.

7 The International Labour Organization (ILO) defines these as "all those workers who hold paid employment jobs, which are those where the incumbents hold employment contracts which give them a basic remuneration not directly dependent upon the revenue of the unit for which they work."

8 In the EGP class scheme, the categories of manual supervisors, skilled worker, unskilled worker, and farm labor are generally considered as part of the working class; Leiulsfrud, Bison, and Jensberg 2005. In the Oesch eight-class scheme, production workers (including employees in the industrial and agricultural sector), service workers, and office clerks, although relying on a different work logic, could be both considered as part of the working class; Oesch 2006. In more recent works, clerks are excluded from the working class; Rennwald and Evans 2014; Oesch and Rennwald 2018.

9 In their recent contribution, Abou-Chadi and Wagner 2019 show that trade unions still play a crucial role in the mobilization of the working class.

10 Refer to the online appendix for further discussion on these criteria.

11 In this regard, see figures $\mathrm{A} 1$ and $\mathrm{A} 2$ in the online appendix.

12 The association between ILO and OECD data is almost perfect (Pearson's $r=.92$ and .95 for size and homogeneity, respectively). To deal with missing data for the two variables, we have proceeded with linear interpolation. This procedure is logically acceptable since the observations in a given country tend to follow a predictable linear trend over time so that each observation is closely linked to the previous and the following ones.

13 Data refer to net union membership (students, unemployed or retired members are excluded).

14 For Greece, excluded from the MAPP project, we have relied on Mair and Van Biezen 2001 and Van Biezen, Mair, and Poguntke 2012. For Luxembourg, the source is Schlager and Weisblatt 2006.

15 Such decline over time is strong and significant for industrial working-class size, working-class homogeneity, and class partisan density. By contrast, in the case of total working class and trade union density the negative trend over time is almost negligible.

16 For more detailed cross-country variations of all classrelated variables, see figures $\mathrm{A} 3-\mathrm{A} 9$ in the online appendix.

17 For Greece, Portugal, and Spain, excluded from Bartolini's study, data until the 1970s have been taken from Lane and Ersson 1987, 58, 67.

18 With reference to the welfare state and labor variables, we have calculated the difference between the item "welfare expansion" (per504) and the item "welfare limitation" (per505), and "labor group positive" (per701) and "labor group negative" (per702), 
respectively. All the other selected items refer to positive references and have no corresponding negative item. For further details on the index, see the discussion in the online appendix.

19 For a brief discussion on this variable, see the online appendix.

20 Polarization index $=$

$$
\sqrt{ }\left\{\sum_{i=1}^{n}(\text { party vote share }) *\left(\frac{\left[\text { party } \frac{L}{R} \text { score-party ystem average } \frac{L}{R} \text { score }\right]}{5}\right)^{2}\right\},
$$

where i represents individual parties; Dalton 2008. Data on Left/Right positioning for each party are taken from the CMP; Volkens et al. 2019. As clearly stated in the literature, high levels of ideological polarization make class issues clearer and party choices consequential compared to the opposite situation where the ideological differences between parties are blurred; Jansen, Evans, and De Graaf 2013; Evans and Tilley 2017.

21 The reference for data collection is Bormann and Golder 2013. For mixed electoral systems, the total number of seats is divided by the sum of the number of districts in which seats are allocated in each tier; Johnson and Wallack 2012.

22 Given that panels are unbalanced (the number of electoral periods within panels ranges between nine and twenty-six and electoral periods are noncontemporaneous), contemporaneous correlation across panels (one of the assumptions of the PCSE) has been ruled out. Moreover, the Prais-Winsten transformation has been preferred to the use of the lagged dependent variable to preserve sample size and degrees of freedom; Harbers 2010. Further robustness checks are presented in tables A5-A9 in the online appendix.

23 All models are significant (as witnessed by the Wald Chi-square statistics) and explain a substantive portion of class bloc vote share in post-World War II Western Europe (the R-squared ranges between $47.9 \%$ and $49.1 \%)$. Moreover, data show no issues of multicollinearity, as the Variance Inflation Factor in Model 1 of table 1 ranges between 1.2 and 2.4.

24 Moreover, table A4 separately tested the effects of the different socio-structural and organizational variables on left electoral mobilization (see the related discussion in the online appendix).

25 Note also that by adding further controls for party system fragmentation, various measures of turnout, economic indicators (GDP growth rate and unemployment) such results hold. The same applies by controlling for government participation of class bloc parties in the previous legislature; see AbouChadi and Wagner 2019; Benedetto, Hix, and Mastrorocco 2020. Further, we built a categorical variable having value 0 if all class bloc parties were in the opposition in the legislature preceding the election, 1 if at least one class bloc party was in government, and 2 if at least one class bloc party held the position of prime minister in the same period. The findings do not change by excluding one control variable at a time. Results are available upon request.

26 All class cleavage-related variables in tables 1 and A4 have been standardized and rescaled to a $0-100$ range, so the respective coefficients can be compared. In terms of standard deviations, if social group strength and organizational density increase by one standard deviation, class bloc vote share increase by 2.3 and 3.3 percentage points, respectively. Furthermore, among the control variables, the only significant predictor at $\mathrm{p}<0.05$ in the general model is the dummy for thirdwave democracies, which has a powerful positive effect. This means that all else equal, Southern European countries have a stronger class bloc compared to the rest of Western Europe. Finally, consistent with Benedetto, Hix, and Mastrorocco 2020, 5 , the economic left emphasis index is negatively associated with class bloc electoral support, although the relationship is significant only at $\mathrm{p}<.10$. This means that class bloc parties gain votes as far as they de-emphasize traditional economic left goals.

27 We have also replicated the regressions in table 1 only for the period 1946-1980 in the subset of thirteen countries (Austria, Belgium, Denmark, Finland, France, Germany, Ireland, Italy, Netherlands, Norway, Sweden, Switzerland, and United Kingdom) included in Bartolini's 2000 analysis. Substantive results are the same as in table 1 , with the obvious difference that class cleavage-related aspects do not decline over time until 1980 (i.e., H4, found later in the text). Results are reported in table A8 in the online appendix.

28 Although the interaction term is not significant, the coefficient of organizational density is statistically significant in both Models 1 and 6 .

29 Notice that by replacing organizational density with class partisan density, the substantive result is exactly the same.

30 This result is consistent with Jansen, Evans, and De Graaf 2013, 391, who conclude their analysis by stating that "we did not find evidence for the idea that left-right positions of left-wing parties alone influence the association between class and vote."

31 Figure 7 clearly shows that the association between organizational density and class bloc vote share is no longer significant since the mid-1990s.

32 We have also replicated Models 3 and 4 of table 1 by replacing the linear time variable with a categorical variable for decades (with the 1950s as the reference category, see table A7 in the online appendix). The results confirm the partial rejection of $\mathrm{H} 4$, as the marginal effect of social group strength on class bloc 
electoral support does not significantly vary over time, while that of organizational density significantly declines in the 2010s (see also figure A10 in the online appendix).

\section{References}

Abou-Chadi, Tarik, and Markus Wagner. 2019. "The Electoral Appeal of Party Strategies in Postindustrial Societies: When Can the Mainstream Left Succeed?" Journal of Politics 81(4): 1405-19.

Adam, Antonis, and Stamatia Ftergioti. 2019. "Neighbors and Friends: How Do European Political Parties Respond to Globalization?" European Journal of Political Economy 59: 369-84.

Adcock, Robert, and David Collier. 2001. "Measurement Validity: A Shared Standard for Qualitative and Quantitative Research.” American Political Science Review 95(3): 529-46.

Alesina, Alberto, Arnaud Devleeschauwer, William Easterly, Sergio Kurlat, and Romain Wacziarg. 2003. "Fractionalization." Journal of Economic Growth 8(2): 155-94.

Bartolini, Stefano. 2000. The Political Mobilization of the European Left, 1860-1980: The Class Cleavage. Cambridge: Cambridge University Press.

Bartolini, Stefano, and Peter Mair. 2007[1990]. Identity, Competition, and Electoral Availability: The Stabilisation of European Electorates, 1885-1985. Colchester: ECPR Press.

Beck, Nathaniel, and Jonathan N. Katz. 1995. "What to Do (and Not to Do) with Time-Series-Cross-Section Data." American Political Science Review 89(3): 634-47.

Beck, Nathaniel, and Jonathan N. Katz. 2007. "Random Coefficient Models for Time-Series Cross-Section Data: Monte Carlo Experiments." Political Analysis 15: 182-95.

Benedetto, Giacomo, Simon Hix, and Nicola Mastrorocco. 2020. "The Rise and Fall of Social Democracy, 1918-2017.” American Political Science Review 114(3): 928-39. https://doi.org/10.1017/ S0003055420000234.

Berry, William D., Matt Golder, and Daniel Milton. 2012. "Improving Tests of Theories Positing Interaction." Journal of Politics 74(3): 653-71.

Best, Robin E. 2011. "The Declining Electoral Relevance of Traditional Cleavage Groups.” European Political Science Review 3(2): 279.

Bormann, Nils-Christian, and Matt Golder. 2013. "Democratic Electoral Systems around the World, 1946-2011." Electoral Studies 32(2): 360-69.

Caramani, Daniele. 2004. The Nationalization of Politics: The Formation of National Electorates and Party Systems in Western Europe. Cambridge: Cambridge University Press.
Clark, Terry Nichols, and Seymour Martin Lipset, eds. 2001. The Breakdown of Class Politics: A Debate on PostIndustrial Stratification. Baltimore: Johns Hopkins University Press.

Costalli, Stefano, and Andrea Ruggeri. 2019. "The LongTerm Electoral Legacies of Civil War in Young Democracies: Italy, 1946-1968." Comparative Political Studies 52(6): 927-61.

Dalton, Russell J. 2002. "Political Cleavages, Issues, and Electoral Change." In Comparing Democracy 2: New Challenges in the Study of Elections and Voting, ed. Lawrence LeDuc, Richard G. Niemi, and Pippa Norris, 319-342. London: Sage.

- 2008. "The Quantity and the Quality of Party Systems: Party System Polarization, Its Measurement, and Its Consequences." Comparative Political Studies 41(7): 899-920.

- 2013. Citizen Politics: Public Opinion and Political Parties in Advanced Industrial Democracies. Thousand Oaks, CA: CQ Press.

Döring, Holger, and Philip Manow. 2019. "Parliaments and Governments Database (ParlGov): Information on Parties, Elections and Cabinets in Modern Democracies." Development version. (http:// www.parlgov.org/).

Drukker, David M. 2003. "Testing for Serial Correlation in Linear Panel-Data Models." Stata Journal 3(2): 168-77.

Elff, Martin. 2007. "Social Structure and Electoral Behavior in Comparative Perspective: The Decline of Social Cleavages in Western Europe Revisited." Perspectives on Politics 5(2): 277-94.

Emanuele, Vincenzo. 2018. Cleavages, Institutions, and Competition. Understanding Vote Nationalization in Western Europe (1965-2015). London: Rowman and Littlefield/ECPR Press.

Erikson, Robert, John H. Goldthorpe, and Lucienne Portocarero. 1979. "Intergenerational Class Mobility in Three Western European Societies: England, France and Sweden." British Journal of Sociology 30(4): 415-41.

Evans, Geoffrey. 2000. "The continued significance of class voting." Annual Review of Political Science 3(1): 401-417.

Evans, Geoffrey, and James Tilley. 2012. "How Parties Shape Class Politics: Explaining the Decline of the Class Basis of Party Support." British Journal of Political Science 42(1): 137-61.

Evans, Geoffrey, and James Tilley. 2017. The New Politics of Class: The Political Exclusion of the British Working Class. Oxford: Oxford University Press.

Flanagan, Scott C., and Russell J. Dalton. 1984. "Parties under Stress: Realignment and Dealignment in Advanced Industrial Societies." West European Politics 7(1): 7-23. 
Franklin, Mark N., Thomas T. Mackie, and Henry Valen, eds. 1992. Electoral Change: Responses to Evolving Social and Attitudinal Structures in Western Countries.

Cambridge: Cambridge University Press.

Fuchs, Dieter, and Hans-Dieter Klingemann. 1990. "The Left-Right Schema." In Continuities in Political Action: A Longitudinal Study of Political Orientations in Three Western Democracies, ed. M. Kent Jennings and Jan W. Van Deth, 203-234. Berlin: De Gruyter.

Garzia, Diego. 2014. Personalization of Politics and Electoral Change. Basingstoke: Palgrave Macmillan.

Gingrich, Jane, and Silja Häusermann. 2015. "The Decline of the Working-Class Vote, the Reconfiguration of the Welfare Support Coalition and Consequences for the Welfare State." Journal of European Social Policy 25(1): 50-75.

Goldberg, Andreas C. 2020. "The Evolution of Cleavage Voting in Four Western Countries: Structural, Behavioural or Political Dealignment?" European Journal of Political Research 59(1): 68-90.

Goldthorpe, J. 1982. "On the Service Class, Its Formation and Future." In Social Class and the Division of Labour, ed. A. Giddens and G. Mackenzie, 162-185.

Cambridge: Cambridge University Press.

Harbers, Imke. 2010. "Decentralization and the Development of Nationalized Party Systems in New Democracies." Comparative Political Studies 43(5): 606-27.

Hooghe, Liesbet, Gary Marks, and Carole J. Wilson. 2002. "Does Left/Right Structure Party Positions on European Integration?" Comparative Political Studies 35 (8): 965-89.

Huntington, Samuel. 1991. The Third Wave: Democratization in the Late Twentieth Century. Norman: University of Oklahoma Press.

Imai, Kosuke, and In Song Kim. 2019. "When Should We Use Unit Fixed Effects Regression Models for Causal Inference with Longitudinal Data?" American Journal of Political Science 63(2): 467-90.

Inglehart, Ronald. 1977. The Silent Revolution: Changing Values and Political Styles in Advanced Industrial Society. Princeton, NJ: Princeton University Press.

_. 1984. "The Changing Structure of Political Cleavages in Western Societies." In Electoral Change in Advanced Industrial Democracies: Realignment or Dealignment, ed. Russell Dalton, Scott C. Flanagan, and Paul Allen Beck, 25-69. Princeton, NJ: Princeton University Press.

Jansen, Giedo, Geoffrey Evans, and Nan Dirk De Graaf. 2013. "Class Voting and Left-Right Party Positions: A Comparative Study of 15 Western Democracies, 1960-2005." Social Science Research 42(2): 376-400.

Johnson, Joel W., and Jessica S. Wallack. 2012. "Electoral Systems and the Personal Vote.” Accessed January
7, 2020 (https://dataverse.harvard.edu/dataset.xhtml? persistentId=hdl:1902.1/17901).

Karreth, Johannes, Jonathan T. Polk, and Christopher S. Allen. 2013. "Catchall or Catch and Release? The Electoral Consequences of Social Democratic Parties' March to the Middle in Western Europe." Comparative Political Studies 46(7): 791-822.

Katz, Richard S., and Robin Kolodny. 1994. "Party Organization as an Empty Vessel: Parties in American Politics." In How Parties Organize: Change and Adaptation in Party Organizations in Western Democracies, ed. Richard Katz and Peter Mair, 24-29. London: Sage.

Kirchheimer, Otto. 1966. "The Transformation of the Western European Party System.” In Political Parties and Political Development, ed. Joseph La Palombara and Myron Weiner, 177-200. Princeton, NJ: Princeton University Press.

Kitschelt, Herbert. 1994. The Transformation of European Social Democracy. Cambridge: Cambridge University Press.

Knutsen, Oddbjørn. 2007. "The Decline of Social Class?” In The Oxford Handbook of Political Behavior, ed. Russell J. Dalton and Hans-Dieter Klingemann, 457-480. Oxford: Oxford University Press.

- 2018. Social Structure, Value Orientations and Party Choice in Western Europe: A Comparative Longitudinal Study. Basingstoke: Palgrave Macmillan.

Kriesi, Hanspeter. 1998. "The Transformation of Cleavage Politics: The 1997 Stein Rokkan Lecture." European Journal of Political Research 33(2): 165-85.

Lane, Jan-Erik, and Svante Ersson. 1987. Politics and Society in Western Europe. London: Sage.

Leiulfsrud, Håkon, Ivano Bison, and Heidi Jensberg. 2005. Social Class in Europe: European Social Survey 2002/3. Trondheim: NTNU Samfunnsforskning/ NTNU Social Research Ltd.

Lijphart, Arendt. 1999. Patterns of Democracy: Government Forms and Performance in Thirty-six Countries. New Haven, CT: Yale University Press.

Lipset, Seymour Martin, and Stein Rokkan. 1967. "Cleavage Structures, Party Systems and Voter Alignments: An Introduction." In Party Systems and Voter Alignments: Cross-National Perspectives, ed. Seymour Martin Lipset and Stein Rokkan, 1-64. New York: Free Press.

Mainwaring, Scott, and Edurne Zoco. 2007. "Political Sequences and the Stabilization of Interparty Competition: Electoral Volatility in Old and New Democracies." Party Politics 13(2): 155-78.

Mainwaring, Scott, Carlos Gervasoni, and Annabella España-Najera. 2017. "Extra-and Within-System Electoral Volatility.” Party Politics 23(6): 623-35.

Mair, Peter. 2007. "Left-Right Orientations." In The Oxford Handbook of Political Behavior, ed. Russell J. 
Dalton and Hans-Dieter Klingemann, 206-222.

Oxford: Oxford University Press.

_. 2008. "The Challenge to Party Government." West European Politics 31(1-2): 211-34.

Mair, Peter, and Ingrid Van Biezen. 2001. "Party Membership in Twenty European Democracies, 1980-2000." Party Politics 7(1): 7-21.

Müller-Rommel, Ferdinand, ed. 1989. New Politics in Western Europe: The Rise and Success of Green Parties and Alternative Lists. Boulder, CO: Westview Press.

Nieuwbeerta, Paul, and Wout Ultee. 1999. "Class Voting in Western Industrialized Countries, 1945-1990: Systematizing and Testing Explanations." European Journal of Political Research 35(1): 123-60.

Oesch, Daniel. 2006. "Coming to Grips with a Changing Class Structure: An Analysis of Employment Stratification in Britain, Germany, Sweden and Switzerland.” International Sociology 21(2): 263-88.

Oesch, Daniel, and Line Rennwald. 2018. "Electoral Competition in Europe's New Tripolar Political Space: Class Voting for the Left, Centre-Right and Radical Right." European Journal of Political Research 57(4): 783-807.

Oskarson, Maria. 2005. "Social Structure and Party Choice." In The European Voter: A Comparative Study of Modern Democracies, ed. Jacques Thomassen, 84-105. Oxford: Oxford University Press.

Parks, Richard W. 1967. "Efficient Estimation of a System of Regression Equations when Disturbances Are Both Serially and Contemporaneously Correlated." Journal of the American Statistical Association 62(318): 500-09.

Patsiurko, Natalka, John L. Campbell, and John A. Hall. 2012. "Measuring Cultural Diversity: Ethnic, Linguistic and Religious Fractionalization in the OECD." Ethnic and Racial Studies 35(2): 195-217.

Poguntke, T. 1987. "New Politics and Party Systems: The Emergence of a New Type of Party?" West European Politics 10(1): 76-88.

Przeworski, Adam, and John Sprague. 1986. Paper Stones: A History of Electoral Socialism. Chicago: University of Chicago Press.
Pulzer, Peter. 1967. Political Representation and Elections in Britain. London: Allen and Unwin.

Rennwald, Line, and Geoffrey Evans. 2014. "When Supply Creates Demand: Social Democratic Party Strategies and the Evolution of Class Voting." West European Politics 37(5): 1108-35.

Roberts, Kenneth M., and Erik Wibbels. 1999. "Party Systems and Electoral Volatility in Latin America: A Test of Economic, Institutional, and Structural Explanations." American Political Science Review 93(3): 575-90.

Rokkan, Stein. 1970. Citizens, Elections, Parties. Oslo: Universitetsforlaget.

Rose, Richard, and Derek W. Urwin. 1970. "Persistence and Change in Western Party Systems since 1945." Political Studies 18(3): 287-319.

Sartori, Giovanni. 1982. Teoria dei partiti e caso italiano. Milano: Sugarco.

Schlager, Neil, and Jayne Weisblatt, eds. 2006. World Encyclopedia of Political Systems and Parties. New York: Facts on File, 4th ed.

Stimson, James A. 1985. "Regression in Time and Space: A Statistical Essay." American Journal of Political Science 29(4): 914-47.

Van Biezen, Ingrid, Peter Mair, and Thomas Poguntke. 2012. "Going, Going, ... Gone? The Decline of Party Membership in Contemporary Europe." European Journal of Political Research 51(1): 24-56.

Van Haute, Emilie, and Emilien Paulis. 2016. "MAPP Dataset.” Accessed January 7, 2020. (www.projectmapp.eu. doi:10.5281/zenodo.61234).

Visser, Jelle. 2016. "ICTWSS Database, Version 5.1." Amsterdam: Amsterdam Institute for Advanced Labour Studies (AIAS), University of Amsterdam. Accessed January 7, 2020. www.uva-aias.net/en/ictwss.

Volkens, Andrea, Pola Lehmann, Theres Matthieß, Nicolas Merz, Sven Regel, and Bernhard Weßels. 2019. "The Manifesto Data Collection. Manifesto Project (MRG/CMP/MARPOR). Version 2019b.” Berlin: Wissenschaftszentrum Berlin für Sozialforschung (WZB). Accessed January 7, 2020 https:// doi.org/10.25522/manifesto.mpds.2019b. 